\title{
Caspian Tern at Regina
}

by Frank Brazier, Regina

Although I have a record in my field notes of an unconfirmed sighting at dusk May 28, 1958, no Caspian Tern (Hydroprogne caspia) has ever been reported in the Regina area. They have, however, been seen at Old Wives' Lake and they breed at Dore Lake far to the north. In the early evening of July 22, 1960, Elmer and Reg Fox and I were on the easit side of Wascana Marsh hoping to find that the Ccmmon and Forster's Ternis had re-nested after the disastrous flooding of June (they had not) when I spotted a black-capped white tern flying low on the wesit side of the Marsh. Happily it was a dull day so that I could see it well even against the evening sky. It turned and came towards us and we could see by camparison with the Ring-billed Gull which accompanied it that this was neither a Common nor a Forster's Tern. It was as large, if not larger than the gull, so it was obviously a Caspian Tern. Soon the tern was flying close by and the full details could be seen by all three of us-great red bill, short slightlyforked tail, and huge size. There was no mistaking the Caspian Ternour first necord for the Regina vicinity. The following evening I was on the opposite side of the Marsh on top of the high bank, alone, when a Caspian Tern (probably the same bird) flew up from the Marsh over my head, in brighit sunlight. This was the last time I saw it.

\section{Barn Swallow Nest Successfully Relocated}

by Joe Herperger, Pilat Butte

Last spring, soon after workmen completed the framing of houses for the engineers who are to work on the Hydro Development Dam at Squaw Rapids, on the Saskatchewan River, a pair of Barn Swallows proceeded to build their nest under the eave of one of the new houses. Eggs were laid and hatched resulting in a family of three young swallows. Soon workmen had to put the siding on the house.

What was to be done with the nest of swallows? A kindly carpenter made a rough bracket and transferred the nest of birds into the front vestibule above the door. For weeks the screen was lefit out of the front storm door so the mother bird could come and go, feeding her young brood.
However, finishing carpenters and painters had work to do on the interior of the house. Work on the vestibule was delayed as long as possible, a brase coat of paint being painted on the walls around the nest.

It was at this time, July 29, while working as a finisher, I decided to take a picture of the swallow family, almost ready to take to their wings. I. rigged up a shelf to hold the Zeiss Ikon $35 \mathrm{~mm}$. camera using a $.5 \mathrm{~m}$ close-up lens and a Mecablitz Electronic Flash, at $1 / 100$ sec. Just as mother swallow flew in to feed her brood, I snapped the picture, "Barn Swallows at Squaw Rapids". A week later the birds started flying, and we finished the house.

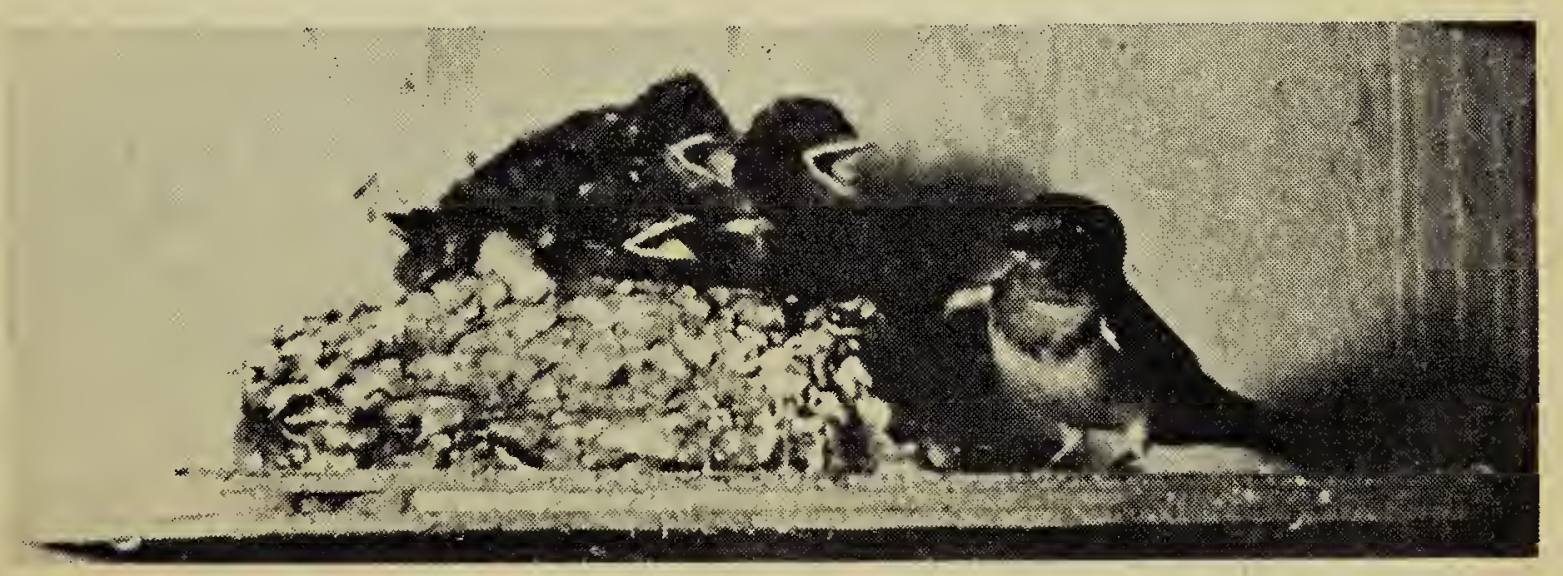

Photo by Joo Herperfor Photo conversion by S.M.N.H. 